\title{
KATEGORIALE SAMLINGER \\ Eller hvordan man fik indført en vis orden i universet i det 18. århundredes britiske zoologi
}

I løbet af det 18. århundrede vandt naturhistoriske studier en hidtidig uset popularitet i Storbritannien. Der blev skrevet, udgivet, købt og læst naturhistoriske bøger, både af et mere populært og af et gennemført filosofisk tilsnit, som langt oversteg tidligere tiders omfang. Bøger med titler som British Zoology (Pennant 1768-1777) eller The Aurelia; or Natural History of English Insects (Harris 1766) blev notoriske bestsellere, der kunne konkurrere med tidens kendeste romaner og mest populære rejsebeskrivelser. På samme tid engagerede en bred skare af især borgerskabets mænd sig i det naturhistoriske projekt. De ikke alene læste og skrev, de deltog også på møder i nogle af de lærde selskaber, der i perioden blomstrede frem; de så på udstoppede fisk og eksotiske fugle i kaffehuse og på museer; de drog til tider selv i felten og indsamlede især nogle af naturens mere pittoreske forekomster som fugle, sommerfugle, blomster og skaller, pressede, tørrede eller ud-stoppede dem, for siden at udstille dem i montre og vitrineskabe i deres private raritetskamre eller overgive dem til de offentlige museer, der netop i denne periode var under etablering. Som en forfatter på Critical Review i 1763 (Critical Review 1763:312) noterede, var naturhistorien ,,ved en art national stiftelse [blevet] tidens yndlingsstudie“. ${ }^{1}$

Mens stenene, blomsterne og dyrene i de naturhistoriske kabinetter oftest blev ordnet efter æstetiske principper, der snarere sigtede mod at fremmane forbløffelse og beundring i tilskueren end mod at uddrage viden om naturen (se ill. 1), var det i den litterære fremstilling, at naturen i denne periode fik sin systematiske, filosofiske behandling. Det var her, naturens mangfoldige forekomster blev sammenlignet, kategoriseret og indskrevet i den altomfattende orden, som de store taksonomiske klassifikationssystemer, der mere end noget andet blev kendetegnende for denne periodes naturhistorie, tilbød. Det var her, at man ved at samle dyrene i kategorier på særegne måder, med en parafrase over Lévi-Strauss (1994 [1962]:20), fik indført en bestemt form for orden i universet.

Det er dette det 18. århundredes yndlingsstudie, jeg skal beskæftige mig med i det følgende med specielt fokus på de zoologiske studier og på den orden, der gennem den zoologiske klassifikation blev etableret. Emnet for nærværende artikel er altså kategorial samling: Det er de kognitive og praktiske processer, der muliggjorde samlingen af dyr i en bestemt form for kategorial orden, som vil være i centrum. Analysen vil overordnet følge det praktiske forløb i det zoologiske arbejde: fra indsamlingen af specifikke dyr i felten over dannelsen af arter i zoologens studerekammer til etableringen af en altomfat- 


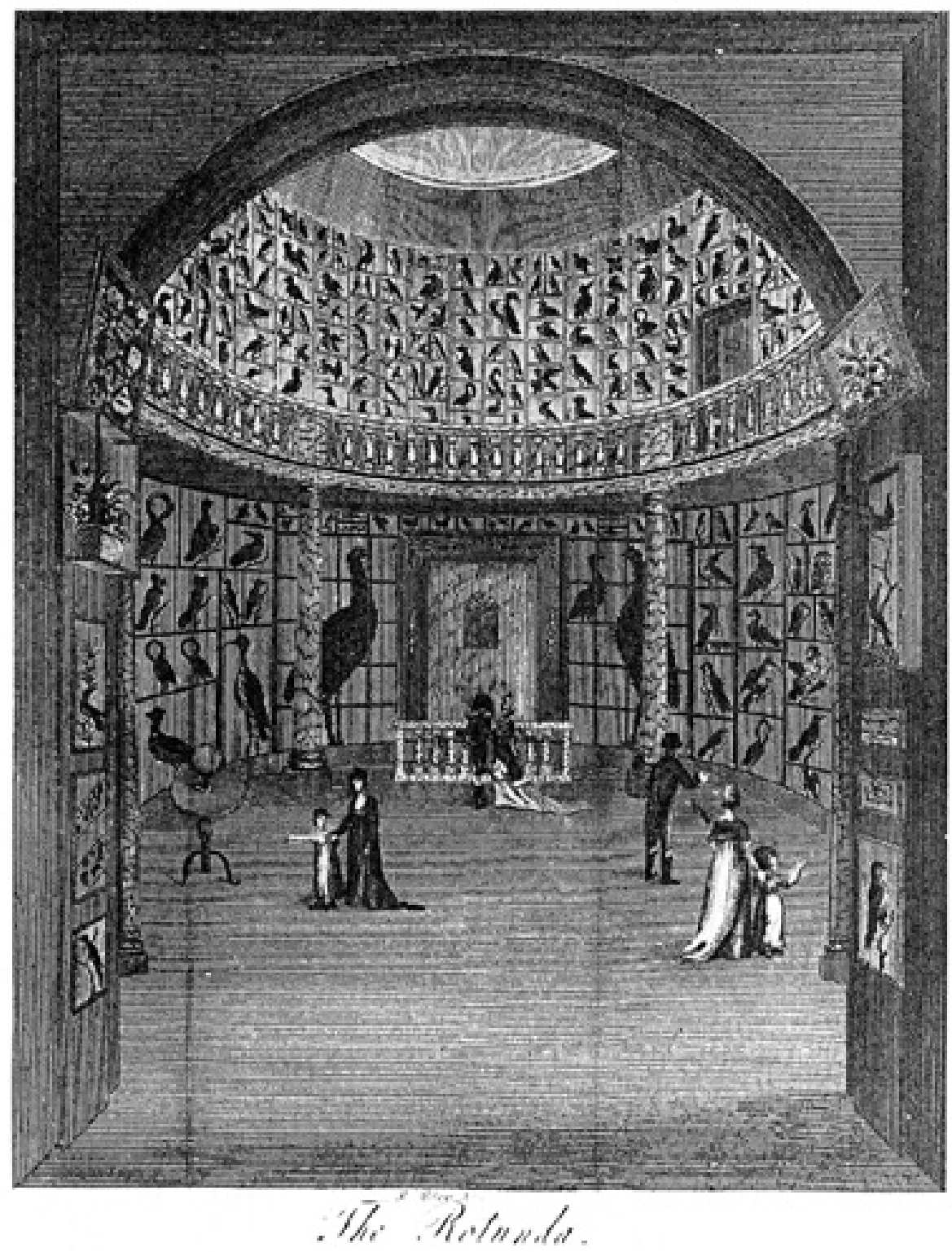

Ill. 1. Det Leverianske Museum i London havde i slutningen af det 18. århundrede en af de betydeligste samlinger af eksotiske dyr i Storbritannien og tiltrak derfor mange besøgen-de - både naturhistorikere og folk, der i højere grad kom for at lade sig underholde. Rotundaen dannede det spetakulære centrum i udstillingsbygningen, fyldt som den var af de mest eksotiske fugle fra alverdens lande. 
tende orden i det store taksonomiske system. Med Lévi-Strauss' diktum in mente, at dyr er gode at tænke med, fordi klassifikationen af dyr giver en model for forståelsen af den menneskelig verden (Lévi-Strauss 1964 [1962]:13), skal jeg artiklen igennem antyde de antropologiske implikationer af den zoologiske klassifikation i samtiden for afslutningsvis mere direkte at diskutere den zoologiske models anvendelse og begrænsninger som homologi for den menneskelige verden. Lad mig som ramme for denne analyse begynde med en skitse af, hvad der umiddelbart kunne forekomme at være en noget paradoksal forståelse af den natur, det hele handlede om, og som blev fundamental for den zoolo-giske bestræbelse.

\section{Den naturlige forvirring og den guddommelige Orden}

I den zoologiske litteratur fra perioden blev det gentagne gange understreget, at naturen for en første, umiddelbar betragtning var uendeligt varieret og i grunden noget forvirrende. Ikke alene var den beboet af et utal af forskellige dyr, planter og mineraler, som den skotske præsident for det lærde selskab Societas naturae studiosorum Richard Kentish bemærkede. Men, i det mindste hvad dyrene og planterne angik, var disse tillige ,flyg-tige“ i deres ,ydre former“, for de ændrede jo udseende, form og farve med årstidernes skiften og årenes gang (Kentish 1787:71). Som en anden naturhistoriker udtrykte det:

De naturlige produktioners mangfoldighed synes [...] i første omgang snarere at forvirre forskeren end at pirre hans opmærksomhed; de forskellige vidundere i Dyre-, Plante- eller Mineralverdenen synes at overgå enhver forståelse, og videnskaben forekommer gold i forhold til dens [naturens] forbløffende frugtbarhed (Brookes 1763-72, I:ix).

Nok mente man, at der et eller andet sted rent faktisk eksisterede en Orden, at der altså bag den $\varnothing$ jensynlige forvirrende mangfoldighed fandtes et, som det ofte kaldtes, ,naturens Design“, som på en gang forklarede både mangfoldigheden og afslørede dens komplette, endelige sammenhæng. Modsat den direkte observerbare natur, der fremstod fysisk-konkret, fragmenteret og altså forvirrende, var denne Orden ideationel, samlende og rationel. Den repræsenterede Guds oprindelige ,arketype“, som Lord Monboddo udtrykte det, for sit værk (Monboddo 1774-92, I:88). Som arketype definerede Ordenen hvert enkelt individs eller - for at bruge en zoologisk terminologi - ,eksemplars“ grundlæggende „Essens“, der bestemte dyrets gestalt og natur. I forhold til denne definitoriske Es-sens fremstod de faktisk observerbare dyr alene som epifænomener (ibid.). Det var her i den guddommelige Orden, at verden og alle dens forekomsters raison d'être var at finde.

Problemet var blot, at mennesket med sine begrænsede og til tider stærkt forvrængende sanser ikke var i stand til at opfatte hverken tingenes Essens eller deres Orden. „En tyk sky“ forhindrede således mennesket i, at erkende den smukkeste og mest storslåede del" af skaberens værk, som en anden skotte, William Smellie (1790, II:430), bemærkede. Kun englene med deres overjordiske, transcendente sanser, og så naturens Skaber selv, kunne formelig se dyrenes Essens og naturens iboende Orden (Monboddo 1774-92, I:183ff.). Mennesket derimod var tvunget til at starte med den forvirrende mangfoldighed af individer og gå omvejen over den taksonomiske klassifikation for blot at nærme sig en vis forståelse af den guddommelige Orden: „Metode og det at ordne tjener som 
Ariadnetråden til at lede det ellers omstrejfende sind gennem den snørklede forvirring i Naturens labyrint", som Robert Kerr (1792:vi) med en parafrase over Carl von Linnés (Linné 1766-68, I:13) berømte formulering af det naturhistoriske projekt fremhævede. ${ }^{2}$

Jeg skal senere vende tilbage til forestillingerne om denne Guds Orden (som jeg skal skrive med stort for at adskille den fra den menneskeskabte orden). Indtil videre er det tilstrækkeligt at bemærke, at forestillingen om, at der fandtes en perfekt Orden i naturen uden for menneskets fatteevne, i og for sig var givet på forhånd, før det zoologiske arbejde overhovedet tog sin begyndelse. At finde frem til denne udgjorde på sin vis formålet med det zoologiske arbejde. Men som et kropsligt væsen med den deraf begrænsede fatteevne var mennesket altså tvunget til at begynde med den håndgribelige, konkrete og fragmenterede mangfoldighed, for at kunne skabe sig en idé om naturens Orden. Lad og-så mig begynde analysen af den zoologiske samling her med en diskussion af zoologens møde med den observerbare, forvirrende natur: Hvordan blev den mangfoldige natur iagttaget og konciperet mere specifikt i den zoologiske praksis? Og hvad betød det for måden, denne naturs forekomster lod sig samle på?

\section{Fragmenterede eksemplarer}

De britiske zoologer præsenterede, som andre lærde i perioden, deres projekt som grundlæggende empirisk og understregede til stadighed nødvendigheden af selv at iagttage og studere naturen for at kunne udtale sig om den med bare en vis sikkerhed. Men skønt de britiske lærde således gennemgående positionerede sig som ,virkelighedens talsmænd“ (Shapin 1994:192), var det ofte slet ikke ude i selve naturen, at deres observationer af de mangfoldige dyr begyndte. Nok var der mange naturhistorikere, som drog ud enten på længere ture i Storbritannien, i Europa og for en meget lille dels vedkommende i mere eksotiske dele af verden. Nok var der mange - de fleste endda, hvis man skal dømme ef-ter beskrivelserne i deres indbyrdes korrespondance - som brugte en del af deres fritid i felten på at studere faunaen i deres umiddelbare nærhed. Men i særdeleshed for de zoologers vedkommende, som beskæftigede sig med hele dyreriget, udgjorde egne observationer i felten en forsvindende lille del af det materiale, de arbejdede med. De var i det store og hele, hvad man i samtiden betegnede som ,skabs-naturalister“. Deres første mø-de med dyrene blev dermed medieret dels af andres øjne og hænder, og dels af forskellige måder at formidle dyrene på fra ofte fjerntliggende steder til zoologens studerekammer. Lad mig her skitsere disse to nært forbundne mediatorer for således at kunne undersøge, hvad der helt præcis udgjorde zoologens empiri: Hvad var det for en form de mangfol-dige dyr antog i kraft af denne formidling? Og hvor var det i første omgang, at zoologerne overhovedet mødte dyrene, hvis ikke i naturen selv?

Mødet med dyrene fandt sted på mange forskellige steder og måder. Zoologerne, der altovervejende tilhørte den bedrestillede del af befolkningen, ${ }^{3}$ sendte deres tjenere i marken for at bringe dem mus eller fugle og ned i floden for at fange fisk og skaldyr (se ill. 2); var de selv i udlandet, veg de ikke tilbage til at få oplysninger om for eksempel slanger fra sydamerikanske indianere (Bancroft 1769:221-2) eller om enhjørninger fra sydafrikanske „hottentotter“ - begge folk, der ellers uden megen tøven blev bestemt som „uciviliserede“ og ,,ignorante“. Zoologerne fremsatte i så godt som hvert eneste brev til deres naturhistorisk interesserede bekendte i og uden for Storbritannien $\emptyset$ nsker om at få 


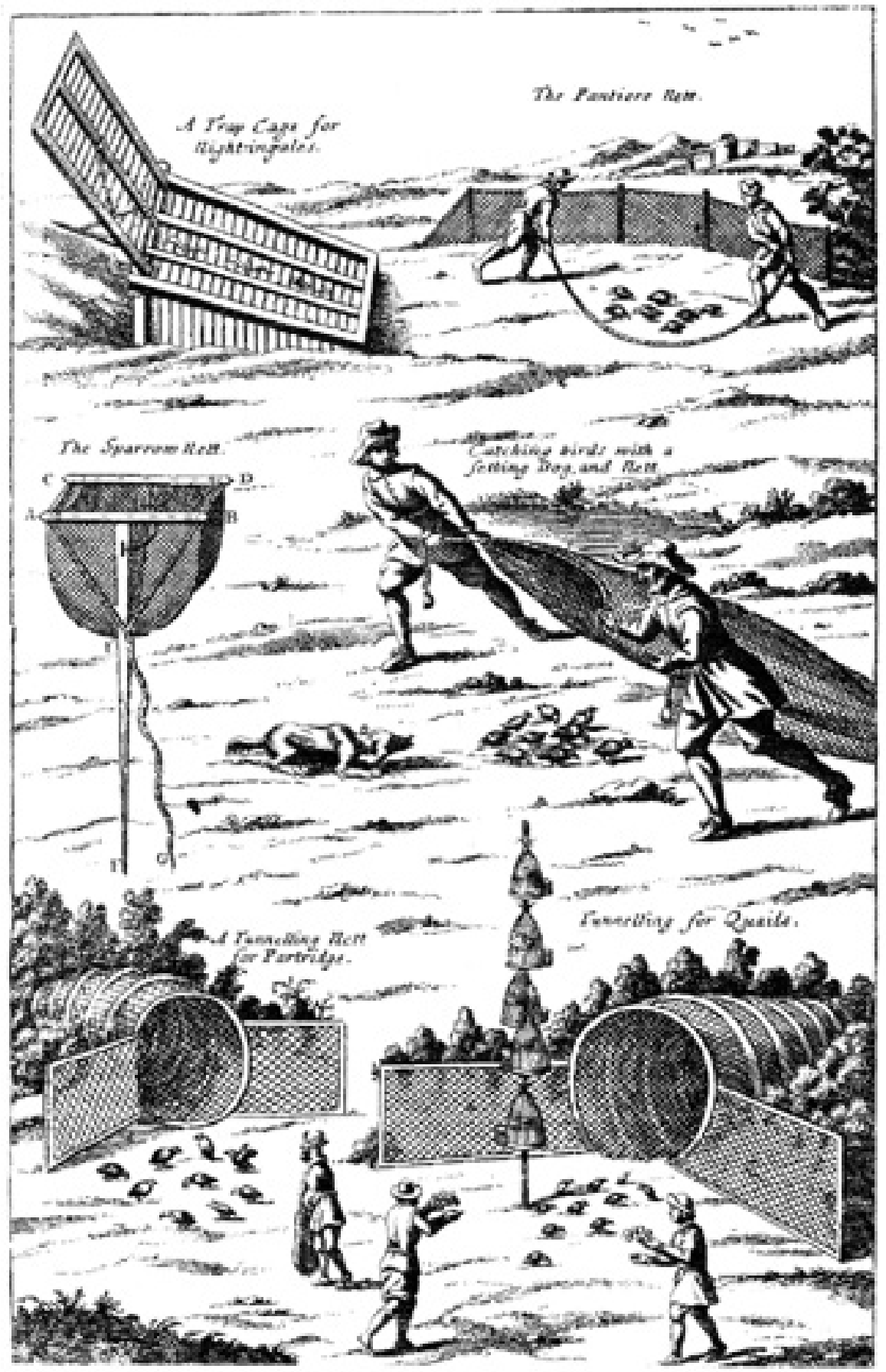

Ill. 2. Fangsten af dyr kunne tage mange former, som her illustreret i et af periodens store ornitologiske værker (Willughby 1678). Bemærk dyremasken, som en bondedreng er trukket i for at fange en flok agerhøner (nederste venstre hjørne). 
oplysninger om dette eller hint dyr på brevskriverens hjemegn og gav selv som oftest andre informationer i bytte; de bønfaldt udenlandsfarende om at observere, beskrive, tegne, samle og konservere dyr og sende hele herligheden hjem; de var flittige besøgende hos de handelsmænd, der hjembragte eksotiske dyr som blandt andet små aber, ostindiske tigre og i særdeleshed eksotiske fugle af enhver slags; de frekventerede skindforretninger i det centrale London og var ofte til stede på markedspladser rundt omkring i Storbritannien, hvor rejsende optrædende fremviste dyr som løver og løvinder, pungdyr, elefanter, chimpanser, talende papegøjer og andre dyr, som ellers hørte en anden og mere eksotisk verden til. Der synes, kort sagt, ikke at have været den kilde, som ikke kunne udnyttes for at tilfredsstille tørsten efter information om alverdens dyr. Nok måtte zoologerne, i det omfang informationen ikke kom fra en velkendt lærd, være påpasselige med ikke at lade sig narre. Det var således velkendt, at hottentotter og indianere i lighed med „almuen i alle nationer stiller deres vildfarelser til skue“, som Edward Bancroft (ibid.) i en evaluering af indianeres værdi som meddelere påpegede det. De ,ignorante“ havde altså en vis tilbøjelighed til at fortælle skrøner, når de skulle berette om dyreverdenen. Ligeså var det almindeligt kendt, at handelsmænd og markedsgøglere altid havde en interesse $\mathrm{i}$ at lyve om dyrene $\mathrm{i}$ deres varetægt eller lige frem helt håndgribeligt lave om på deres fysiognomi for at gøre dem mere eksotiske og hermed $\emptyset$ ge deres handelsværdi: Østerlandske nattergales ben var således angiveligt blevet amputeret for at skabe en sand paradisfugl, der alene bevægede sig ved sine vingers kraft (Willughby 1972 [1678]:2; jf. Jørgensen 1998), relativt almindelige fugles relativt almindelige oprindelsessteder skulle være blevet forfalsket til „meget fjerne og ukendte steder“ og så fremdeles (Edwards 1743-51, II:111). Men i løbet af det 17. og 18. århundrede udvikledes der inden for naturhistorien, som for naturfilosofien mere generelt, et helt repertoire af det, man kunne kalde „kildekritiske“ strategier til at evaluere udsagn fra de mennesker, der opfattedes som mindre troværdige (jf. Shapiro 1983). Takket være denne kildekritik kunne vilde, bønder, tjenere og andre ,ignorante“ inkluderes i skaren af vidensformidlere om konkrete dyr på dette præ-klassifikatoriske niveau, om end ikke på lige fod så dog tilsammen med zoologernes lærde kollegaer.

Når dyrene nåede zoologen, var de som regel ikke længere i live, ja, for de meste var de end ikke til stede i materiel forstand. Nogle dyr, som større pattedyr, ville til tider være blevet flået, tørret og udstoppet; andre, som mindre pattedyr, fugle og slanger, kunne put-tes på glas fyldt med konserverende rom eller brandy; insekter ville ofte være sat på nåle, og kun skallerne af skaldyr som østers og muslinger ville i reglen nå frem. Langt de fleste dyr fik zoologen imidlertid alene kendskab til i repræsenteret form, beskrevet og/eller tegnet. De blev formidlet i det utal af breve, de fleste zoologer udvekslede med en bred skare af mennesker, eller i de rejsebeskrivelser, som i denne periode begyndte at inkorporere naturhistoriske beskrivelser af eksotisk flora og fauna som en næsten obligatorisk del (Pratt 1992:27-8).

Det var med denne ansamling af dyr, formidlet af mange forskellige slags mennesker i mange forskellige former, at zoologens arbejde med at omforme naturens forvirrende mangfoldighed til en orden tog sin begyndelse. Det var denne ansamling af dyr, som i enhver praktisk henseende udgjorde zoologens empiri. På trods af den store forskellighed i kanaler og medier, som dyrene blev formidlet igennem, er det muligt at pege på mere generelle træk ved formidlingen, som formede dyrene på bestemte måder, og som, som vi senere skal se, satte rammer for den måde, de senere kunne klassificeres på. Af- 


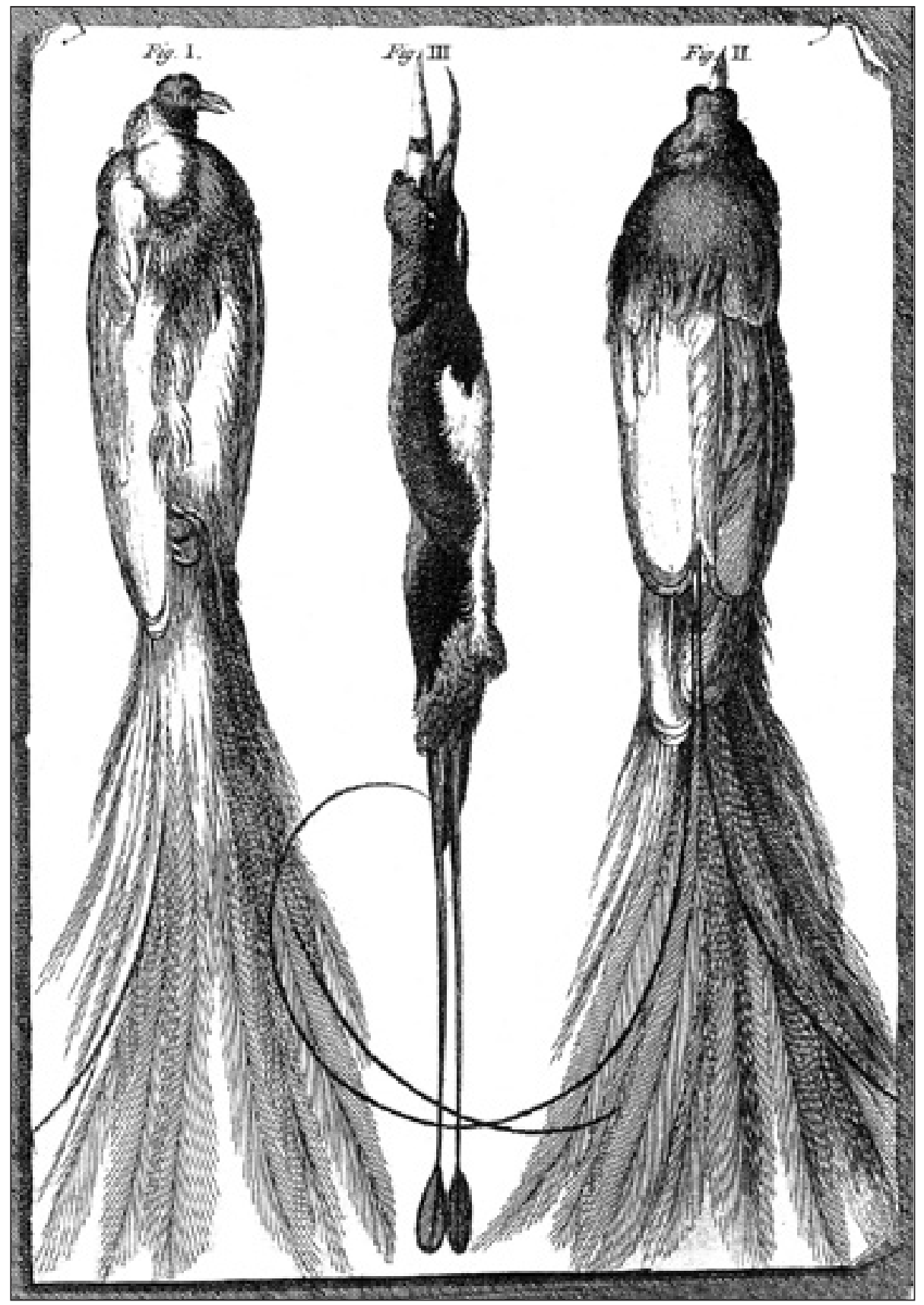

Ill. 3. Tre paradisfugle, hvoraf én i det mindste har benene i behold (Bradley 1721). 
livningen og konserveringen, tegningen eller beskrivelsen, indfangningen og salget eller udstillingen fjernede dyrene fra deres oprindelige kontekst og introducerede dem som objekter i den kulturelle verden. Løsrevet fra deres oprindelige kontekst, kom dyrene alt-overvejende til at fremstå som fragmentariske eksemplarer. Ydermere var det karakte-ristisk for disse dyr, at det først og fremmest var dyrenes morfologiske træk, det vil sige dyrenes ydre former, som blev formidlet gennem disse forskellige kanaler. De konserverede dyr var, indlysende nok, blevet reduceret til morfologiske størrelser igennem udstopningens fastfrysning eller nålens spidning; men også i skrift og tegning var det først og fremmest dyrenes former og farver, der blev gengivet, mens for eksempel deres behavioristiske mønstre, deres parringsakter, deres relation til deres habitat - alt det, der kort sagt vedrørte deres liv i tid og rum, almindeligvis kun blev yderst sporadisk berørt.

Det var med denne ophobning af dyr, at zoologens arbejde med at samle alverdens dyr i en orden startede. Men som filosoffen James Harris påpegede, var det at have kendskab til sådanne enkelt individer faktisk slet ikke det samme som at have viden om dyr: „For kun i det tilfælde kan en hvilken som helst Partikel siges at være blevet kendt, hvor vi ved at hævde, at den er en Mand, eller et Dyr, eller noget lignende, henfører den til nogle sådanne vidtfavnende, eller generelle Ideer" (Harris 1751:370-2; kurs. i org.). De enkelte løsrevne dyr, der på forskellig vis nåede frem til zoologen, bar ingen mening eller viden i sig selv. For at få viden om dyrene måtte de løsrevne eksemplarer relateres til hinanden og gennem en sammenligning samles i kategorier: „Vores videnskabs vej er sammenligningen af et dyr med et andet via hukommelsen [hvor informationer om andre dyr ville være oplagret] for herigennem at blive i stand til at beskrive det", som zoologen Gilbert White skrev til en af sine kollegaer (White til Pennant 1770). Først med samlingen af eksemplarerne i kategorier blev dyrene omformet til vidensobjekter. Det er denne samlings metoder, jeg i det følgende skal kigge nærmere på.

Før jeg går i gang, er det dog værd at bemærke, at der med overgangen fra den „præ-videnskabelige“ ophobning af eksemplarer til den videnskabelige samling af dyr i et taksonomisk system skete en udskilning blandt de menneskelige agenter i det zoologiske arbejde. Hvor selv de klassifikatorisk ignorante grupper af mennesker - som bønderne og indianerne - havde kunnet bidrage med information om de konkrete, observerbare dyr, var det alene den lærde, der mentes i stand til at udvinde viden af denne hob. Det var nem-lig alene den lærde, der gennem uddannelse og studier antoges at have udviklet sin ræsonneringsevne tilstrækkeligt til at være i stand til at kunne sammenligne og hermed skabe generelle kategorier. Almuen var på sin side, med John Lockes metafor, bundet som en ,arbejdshest“" til dagligdagens slid og slæb for at kunne stille sin sult, og ville således ikke have overskud og tid til at udvikle sine tankeevner. Dens evne til at opnå viden blev dermed, som Locke konkluderede, ,,almindeligvis [...] så ringe som dens formue“ (Locke 1997 [1706]:604; IV,xviii,16). Filosoffens og den ignorantes idéer om verden blev hermed grundlæggende forskellige, som Lord Monboddo også påpegede:

[V]idenskabsmandens eller filosoffens idé [...] er meget forskellig fra almuens. For i det første tilfælde er den fuldstændig adskilt og abstraheret fra enhver materiel sammenhæng, idet alle de forskellige objekter, hvorfra den [idéen] er samlet, udelades af betragtning, og kun det, som de har til falles, tages i betragtning; mens almuen aldrig foretager denne adskillelse helt, men til stadighed kun ser det enkelte i de mange; blandt dem [almuen] er menneske for eksempel ikke andet end et begreb, der henviser til Peter, James, og John og andre af artens individer; og når de vil forklare deres forestilling om en ting, kan de ikke gøre dette uden ved et eksempel (Monboddo 1774, I:96-7; kurs. i org.). 
Mens den ignorante af omstændighederne blev fastholdt i det konkretes forvirring, kunne den lærde altså med sit oplyste sind (mind) hæve sig op over verdens forvirrende specificitet ved at danne arter af mangfoldigheden af dyr. Lad os følge den lærde i sit fore-havende. Jeg skal begynde på den zoologiske samlings laveste trin med en diskussion af artsbegrebet i det 18. århundrede for dernæst at vende mig mod den taksonomiske klassifikations højere niveauer.

\section{Arter}

Umiddelbart kan det synes, som om vores idé om en ,art“ har en indlysende pendant i na-turen. At en grå, en sort og en stribet kat på en eller anden måde hører sammen i en fæl-les kategori, forekommer indlysende for de fleste. Og ser man på krydskulturelle etno-zoologiske og -botaniske studier bekræftes dette indtryk da også: På tværs af tider og samfund har der - hvis man ser bort fra væsentlige dele af den evolutionære biologi - i al væsentlighed været en bemærkelsesværdig enighed om, hvilke eksemplarer der skulle inkorporeres i hvilke kategorier på artsniveau (Atran 1990:kap. 2). På den anden side er det ikke alene umuligt at observere en ,,art“ nogetsteds i naturen - den lader sig kun danne i tankerne - men hvis man følger artsbegrebets historie, viser det sig også, at måden en art konciperes på, har varieret så stærkt gennem tiden og på tværs af samfund, at det forekommer legitimt også at tale om et kulturelt element i artsbegrebet. Det er med denne kulturelle forskel for $\varnothing$ je, jeg i det følgende skal undersøge det 18. århundredes samling af eksemplarer $\mathrm{i}$ arter.

I det mindste siden det 16. århundrede havde en art været defineret empirisk som en gruppe af eksemplarer, der på en eller anden måde - man var meget langt fra enige på dette punkt - var i stand til at reproducere sig selv gennem avl af frugtbart afkom. Den italienske botaniker Andrea Cesalpino (1519-1603) tilskrives almindeligvis æren af at have introduceret dette artsbegreb med denne definition af en botanisk art: ,mager avler overalt mager, ifølge deres natur og af samme art" (Cesalpino 1583:26). Den biologiske art henviste således til en selvreproducerende slægtsgruppe, som principielt lod sig observere empirisk. Skønt denne definition af arten sikrede artens ontologiske status, var den imidlertid langt fra tilstrækkelig som ramme for definitionen af den enkelte art. Ikke alene var det som oftest umuligt i praksis for zoologen at iagttage, hvem der rent faktisk parrede sig med hvem - tegninger og beskrivelser, udstoppede og i spiritus konserverede dyr gav naturligvis ingen information om sådanne forhold fra sig. Men af mere fundamental betydning var desuden det forhold, at skønt parringsakten principielt kunne ud-pege artsfæller, gav den ingen oplysninger om det, der i det 18. århundrede blev mest interessant at vide nogen om, nemlig om artens ,definitive natur“. Som Lord Monboddo sagde: For at mennesket kunne ,siges at kende“ en art, måtte han være i stand til at definere dens særlige, distinktive kendetegn, og dette kunne alene ske gennem sammenligningen af en art med en anden (Monboddo 1774-92, I:68-9).

For mere præcist at forstå, hvad denne samling af eksemplarer i arter i grunden indebar, vil det, før vi vender os mod den zoologiske klassifikation selv, være frugtbart at se lidt nærmere på den samtidige forestilling om den kognitive operation, som dannede grundlaget for klassifikationen. Dette epistemologiske aspekt blev til tider berørt i den zoologiske litteratur og blev mere udførligt behandlet i periodens filosofiske litteratur. ${ }^{4}$ Lad os indledningsvis se lidt nærmere på, hvad ,erkendelse“ (understanding) som filo- 
sofisk-kognitivt begreb indebar i det 18. århundrede. Stillet over for den fysiske verden mentes mennesket, den lærde såvel som den ignorante, alene i stand til at opfatte usammensatte elementer (simple elements), som for eksempel en specifik hund, en specifik fugl, en specifik mand som John, Jack eller Dave. ${ }^{5}$ Gennem det menneskelige sanseapparat ville disse usammensatte elementer indprente sig på menneskets sind, hvor de ville blive repræsenteret som ,usammensatte ideer“ (simple ideas) om specifikke ting og som sådanne oplagret i hukommelsen.

For at bevæge sig fra de usammensatte ideers niveau til generelle kategorier, for for eksempel at danne et begreb om en art, måtte sindet træde aktivt i funktion for at generalisere: ,[N]år vi generaliserer, sammenligner vi nødvendigvis, “ som Lord Monboddo observerede: ,Ved at sammenligne ting, opdager vi deres forskelle såvel som deres lig-heder“ (Monboddo 1774, I:68; kurs. i org.). Det var identifikationen af såvel forskelle som ligheder mellem usammensatte idéer, som tillod mennesket at samle disse ideer i generelle kategorier. For det var ved at udpege et træk, som en gruppe af sådanne ideer - for eksempel dyr - delte, og som samtidig adskilte dem fra andre grupper af dyr, at en generel kategori, som en art, kunne etableres. Det var altså, med James Harris' lidt kryptiske, men bestemt ikke utypiske formulering, idet sindet opdagede ,det, der er ET i de MANGE; det, der i ULIGE og FORSKELLIGE ting er LIGEDANNET og ENS [... at] vi når frem til GENERELLE IDÉER“ (Harris 1751:367; vers. og kurs. i org.).

$\mathrm{Nu}$ var der, som Lord Monboddo understregede, altid ,utallige forskelle“ mellem alle ting, ,fordi enhver ting er forskellig fra det, den ikke er“ (Monboddo 1774-92,I:69 (note*)). En given hest ville eksempelvis ikke alene adskille sig på et utal af måder fra en hund, en kat eller en sommerfugl, men forskelle i størrelse, farve, manke, pelsens tekstur, bevægelsesmåde etcetera ville desuden også adskille den fra enhver anden hest og for $\emptyset$ vrigt også fra den selv samme hest dagen i forvejen eller dagen efter. Når man skulle definere en art, var det imidlertid langt fra alle forskelle, der gjorde en forskel. Det var derimod de forskelle, som adskilte en kategori af arter fra en anden nærtstående kategori - heste fra æsler og muldyr for eksempel - der var interessante i denne sammenhæng:

Men det er forskellen fra den samme slags af ting, som gør, at en art kan defineres for sig selv [...]. Og grunden til dette er, at kendskabet til en ting ikke kan blive perfekt, hvilket det burde være i definitionen, med mindre vi kan adskille den fra de ting, som den mest ligner (op.cit.: 68-9).

Selve sammenligningens formål var, som Lord Monboddo senere understregede, at sortere en given arts „tilfældige“ og ,uspecifikke“ kendetegn, som i tilfældet hest: for eksempel dens farve henholdsvis fire ben, fra de for arten „,æælles“, ,,særegne“ og „,essentielle“ kendetegn (op.cit.:98-9). Som Kentish på lignende vis understregede efter at have gjort sin bemærkning om flygtigheden i naturens ydre former, gjaldt det om , gennem grundig opmærksomhed og minutiøse undersøgelser, at [...] bestemme de egenskaber [hos dyr], som hun [dvs. naturen] har karakteriseret som uudslettelige“ (Kentish 1787:71-2). En art kunne altså skabes ved at identificere de kendetegn, der var definitive i den forstand, at de transcenderede tidens indflydelse og samtidigt udpegede de eksklusive ligheder mellem de eksemplarer, der inkluderedes i kategorien.

Et af de helt grundlæggende træk ved det 18. århundredes artsforståelse var således, at arten i lighed med abstrakte kategorier i al almindelighed stod ,i modsætning til alt temporært“, og dermed udtrykte „Eksistensens Perfektion, i forhold til hvilken Tiden 
og dens Distinktioner er fuldstændig ukendte“ (Harris 1751:90-1; jf. 38ff., 159; kurs. i org.). Nok havde arten principielt et empirisk modstykke i en selv-reproducerende slægtsgruppe, men som en abstrakt og semantisk kategori, der var komparativt defineret ved dens forskelle fra andre arter, var den på samme tid løsrevet fra tid og sted. Det var alene i sindets tankeverden, at eviggyldige forskelle og ligheder kunne opdages. For det var alene her, at naturens foranderlighed kunne overkommes.

\section{Samling i praksis}

I princippet kunne en art altså etableres og defineres gennem en simpel sammenligning. I zoologens praktiske arbejde blev denne sammenlignings forl $\varnothing \mathrm{b}$ og dermed dens resultat dog yderligere formet, dels af en række i al væsentlighed uudtalte forestillinger om, hvilke forskelle der gjorde en forskel, det vil sige af en specifik måde at indholdsudfylde idéen om ,de uudslettelige kendetegn“ "på. Dels blev artsdannelsen begrænset af en række fortrinsvis praktiske omstændigheder.

Lad mig starte med definitionen af de definitive træk: Hvis man ser på tværs af de zoologiske værker fra tiden, kan man i zoologernes definition af arternes kendetegn oftest udgjort af en tre-fire træk - observere en klar tendens til systematisk at fremhæve nogle træk og forbigå andre. I det omfang zoologen havde et valg (og det var ikke altid, at han havde mere end et enkelt eksemplar til sin rådighed til at basere sin definition af en art på (f.eks. Anonym 1776:34; Shaw 1792, II:59-60), var det generelt fuldvoksne, men ikke for gamle hanner med klare farvetegninger og uden sygdomme eller skavanker, der blev anvendt i definitionen af en arts definitive kendetegn. Som også John Woodward pointerede det: „Vær omhyggelig med at vælge de smukkeste eksemplarer af en art og sådanne, som er perfekte eller hele“ (Woodward 1696:10; kurs. i org.). Præferencen for perfekte hanner som prototyper for arten er ofte synlig selv i valget af personligt stedord i beskrivelsen af arterne: I de ganske hyppige tilfælde, hvor et dyr ikke beskrives som „,den“ eller „det", betegnedes det med få systematiske undtagelser som „han“ (pelikanen, muldvarpen og katten, alle arter hvis ,,moderlige“ instinkter forekom at være fremherskende, betegnedes derimod oftest med „hun“).

Dette betød ikke, at hunnerne, ungdyrene, de gamle, de syge, de mindre fint farvetegnede og alle de på andre måder uperfekte dyr ikke principielt inkluderedes i en art. Selvfølgelig gjorde de det. De blev oven i købet en gang i mellem beskrevet for sig, ligesom forfatterne også gjorde sig mere generelle overvejelser over forskelle og ligheder mellem æg, larver og insekter, unger og voksne, hanner og hunner. Men den generelle betoning af de perfekte hanners kendetegn som prototypiske for en art havde den konsekvens, at alle de andre på forskellig vis ,uperfekte“ dyr gennemgående blev præsenteret som afledte af, hvis da ikke ligefrem afvigelser fra (Schiebringer 1993:88ff.), den perfekte han (se ill.4). Endvidere var det oftest alene i behandlingen af dyr, der væsentligt og systematisk ændrede form i løbet af deres liv såsom insekter og padder, at forskellige udviklingsstadier blev beskrevet. Også her var det det dyr, der blev anset for at være ,,perfekt“", nemlig det fuldtudvoksede insekt eller padden, som dannede grundlaget for bestemmelsen af de karakteristiske træk (se eksempelvis Smeathman 1781). Samlet kan vi med et lån fra Edwin Ardener (1989:169) sige, at der i artskategorien generelt var en „semantisk tæthed" omkring eksemplarer, der blev regnet for perfekte og i særdeleshed omkring den 

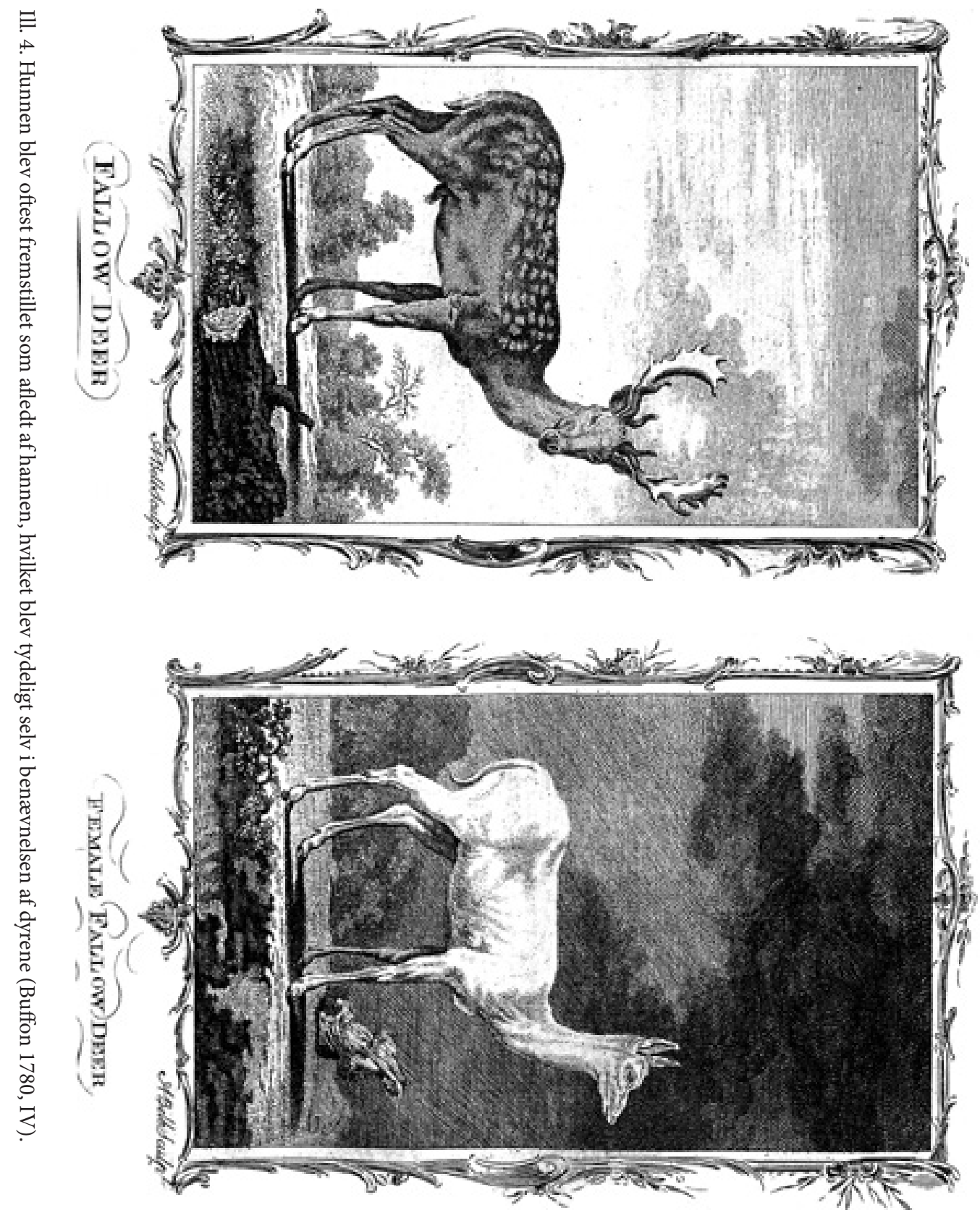
perfekte han: Det var hans træk, der gennemgående blev definitive for arten som sådan.

Denne klare tendens til at lade de perfekte hanner definere en art trækker på en mere generel forståelse af forholdet mellem kønnene i perioden, hvor kvinden også i den menneskelige verden almindeligvis blev fremstillet og forstået i kraft af sine afvigelser fra manden (Schiebinger 1993; jf. Barker \& Chalus 1997). Desuden baserede denne praksis sig også på en ganske bestemt forestilling om perfektionen som den fuldendte realisation af et givent potentiale - i dette tilfælde dyrenes iboende natur - og en bestemt forestilling om det uperfekte - den uvidende i forhold til den lærde, kvinden i forhold til manden, barnet i forhold til de voksne, dyret i forhold til mennesket, hunnen i forhold til hannen og så videre - som mangelfuld i betydningen ukomplet (f.eks. Smellie 1790, I:53ff.). Valget af den perfekte, voksne han som prototype for definitionen af arten havde den væsentlige konsekvens, at flygtigheden i naturens ,ydre former“ kunne overkommes: For at arten også i praksis kunne identificeres ved uudslettelige kendetegn, der per definition var universelle og eviggyldige, måtte zoologerne i naturens flygtige former identificere en konstans, der altså af ikke helt tilfældige grunde blev den perfekte, voksne han.

Skønt det således gennemgående var de perfekte hanners træk, der blev definitive for arten, efterlod dette stadig zoologerne med et væld af forskellige træk at vælge imellem, når de tre-fire definitive træk skulle bestemmes. Hvilke træk, der rent faktisk blev identificeret som en arts kendetegn, varierede fra art til art og fra zoolog til zoolog. Inden for nogle arter, som hunde og heste, ville størrelse og farve eksempelvis ofte blive ladt ude af betragtning, idet de blev betegnet som ,tilfældige størrelser“", mens farve og størrelse i andre tilfælde, som for eksempel i bestemmelsen af sommerfuglearter eller fugle, ofte blev afgørende for definitionen. Inden for zoologien blev de karakteristiske træk altså en variabel, der varierede ikke alene mellem dyrearter, men også mellem zoologer.

I praksis var definitionen af arten yderligere begrænset af den faktiske ansamling af eksemplarer og deres særegne beskaffenhed. Som vi allerede har set ovenfor, var de eksemplarer, som en zoolog rent faktisk havde til sin rådighed, yderst forskelligartede. Det medium, dyrene tilvejebragtes igennem, varierede, som vi også så, stærkt - tørrede, udstoppede, flåede, markeds- eller handelsobjekter, beskrevne eller tegnede og så videre - således at det i sidste instans langt fra altid var eksemplarer af samme slags, der blev sammenlignet: Ikke alene blev tørrede skind og udstoppede dyr sammenlignet med hinanden og med andre forfatteres beskrivelser af lignende dyr. Forfatteres beskrivelser kunne desuden være stærkt varierende: Nogle forfattere beskrev visse dele af et dyr; andre forfattere hæftede sig ved andre; én beskrev, uden nødvendigvis at nævne det, et fuldvoksent dyr, mens en anden beskrev en unge; nogle beskrev en hun, andre en han. ,[B]e-skrivelser er ofte ikke tilstrækkeligt fulde og specifikke," som George Edwards konstaterede, da han fors $\varnothing$ gte at afgøre, om en lille rødvinget papeg $\varnothing j$ e allerede var beskrevet af andre zoologer. Og konsekvensen: ,en udeladelse af selv det mindste kendetegn [i beskrivelsen] kan føre til fejltagelser, når [eksemplarernes] skikkelser er meget nær hinanden“" (Edwards 1758-65, I:54). Selv i de tilfælde, hvor en zoolog med egne $\emptyset$ jne kunne beskue et dyr, ville alle principielt væsentlige træk ikke nødvendigvis være tilgængelige. Et udstoppet dyr lod sig lige så lidt dissekere som et tegnet eller beskrevet dyr, og zoologen var hermed meget ofte på forhånd afskåret fra at anvende anatomiske træk som differentieringskriterie. Men selv i observationen af de ydre morfologiske træk kunne zoologen ikke nødvendigvis stole på det, han så. Under transporten eller i tørringsprocessen kunne dyrene let miste lemmer: Fugle og aber nåede således i nogle tilfælde 
frem til zoo-logen uden haler (Brown 1776:20; Shaw 1792, II:72), en myreslugers skind ændrede sig kendeligt i konserveringsprocessen (Kerr i Linné 1792:104-5), sommerfugles fødder blev oftest beskadiget eller helt destrueret inden de fra alverdens eksotiske lokaliteter nåede frem til de europæiske naturhistoriske kabinetter (Yeats 1773:134) og så videre og så videre. Med en sådan ophobning af dyr i forskelligartede udgaver som zoologens konkrete udgangspunkt, blev hans sammenligningsvirksomhed i praksis begrænset af det, vi kan kalde de til enhver tid tilgængelige træk. Thomas Shaw opsummerede i sin beskrivelse af en abe, der havde mistet halen, de øjensynlige konsekvenser af de utilstrækkeligt tilgængelige træk:

Disse tilfældige lemlæstelser, som af og til optræder hos adskillige eksotiske dyr, fremkalder betydelige fejl i forfatteres beskrivelser, og en ikke ubetydelig forvirring har af denne grund resulteret $\mathrm{i}$ opstillingen og opregningen af forskellige arter af Simiae [aber], som selv med al hjælp fra figurer og beskrivelser stadig er indhyllet i betydelig uklarhed (Shaw 1792, II:72).

Det er svært, for ikke at sige umuligt, at pege på nogle systematiske konsekvenser af disse ,tilfældige lemlæstelser“. Men selve tilstedeværelsen af ,tilfældet“ - og vigtigere endnu zoologernes opmærksomhed på denne tilstedeværelse - underminerede i nogen grad de faktisk skabte arters ontologiske status. De til enhver tid tilgængelige forskelligheder var ikke, som zoologerne meget vel var klar over, nødvendigvis overensstemmende med de essentielle forskelligheder, som Guddommen havde nedlagt i arterne (jf. Locke 1997 [1706]:408; III,vi,30).

Efterhånden som mindre mangelfulde eksemplarer blev hjembragt, som tillod en specificering af de definitive træk, og efterhånden som også eksemplarer af nye arter blev opdaget, som tillod zoologerne mere præcist komparativt at definere allerede kendte arter, ændredes artsdefinitionerne. I det 18. århundrede, hvor stadigt flere eksotiske dyr blev bragt til Storbritannien blev redefinitionen af allerede kendte arter et tilbagevendende tema i de zoologiske værker: I den stadige jagt på de komparativt bestemte helt definitive kendetegn blev en art, måske en anelse ironisk, i praksis til en kategori i forandring.

\section{Orden}

Identifikationen af artens definitive kendetegn blev grundlaget for den videre samling af dyr i den store taksonomiske orden: „Når sådanne karakteristiske kendetegn engang er opdaget“", som Kentish konstaterede, ,kan vi gå videre til systemet og forsøge at klas-sificere selv uendeligheden. Mangfoldigheden vil ikke længere udgøre et problem“ (Kentish 1787:71-2).

Når selv mangfoldigheden, der i udgangspunktet havde forekommet så forvirrende, nu med fastlæggelsen af arternes definitive træk kunne overkommes, skyldtes det, at disse træk blev fundamentet for en yderligere sammenligning: Arter blev sammenlignet med arter, forskelle og ligheder fundet og arterne hermed samlet i mere generelle kategorier. Som Lord Monboddo fastslog, når arterne var dannet,

vil sindet endnu engang anvende dets sammenligningskraft på dem [arterne]; og ved på samme vis at opdage ligheder forme disse ligheder til endnu et sæt af generalier over det første; i forhold til hvilke de, med logikkens sprogbrug, siges at være genusen. Og således 
stiger vi fra det generelle til det [mere] generelle“ (Monboddo 1774-92, I:72).

I princippet blev hele det taksonomiske klassifikationssystem således dannet igennem en opadgående komparativ analyse, hvor identifikationen af ligheder og forskelle mellem kategorier på stadigt højere niveauer gjorde det muligt at samle arter i genera, genera i ordner, ordner i klasser og klasser i riger.

Skønt denne formulering af det klassifikatoriske projekt som induktivt var ideologisk vigtig for zoologernes positionering som ,virkelighedens talsmænd“ også her, er den dog ikke ganske dækkende som beskrivelse af den faktiske klassifikatoriske praksis. Mens den opadgående klassifikation i zoologien var dominerende i definitionen af arter, genera og i nogen grad ordner - og her endda ikke en ren induktiv operation, men medieret, som vi har set, af praktiske og kulturelle forhold - blev denne induktive bevægelse i praksis suppleret af en deduktiv, nedadgående klassifikation, hvor zoologer deducerede sig frem oftest til klassifikationssystemets højere kategorier (riger, klasser og i nogen grad ordner). ${ }^{6}$ I praksis forløb klassifikationen af dyr langs de to akser på en gang. Overhovedet at gå i gang med at samle eksemplarer af dyr i arter (opadgående bevægelse) indebar således en forudgående skelnen mellem planter og dyr (nedadgående bevægelse).

I dette samspil mellem induktiv og deduktiv klassifikation dannedes et komplet taksonomisk, inklusivt hierarkisk system baseret på identifikationen af forskelle og ligheder, hvor arter underordnedes genera, genera underordnedes ordner, ordner underord-nedes klasser og klasser underordnedes riger. Som det 18 . århundredes vigtige opfindelse i forhold til tidligere europæiske naturhistoriske behandlinger af faunaen var det karakteristisk for indførelsen af det taksonomiske system her, at hver enkelt kategori havde én og kun én plads i den taksonomiske tabel.

Også på det klassifikatoriske systems højere niveauer var der blandt zoologerne store variationer mellem de forskelle, der blev fremhævet som afgørende, og hermed mellem de kategorier, der blev skabt. Inden for klassen af kvadrupeder eller firfødder anvendte nogle forfattere eksempelvis dyrenes olfaktoriske organer som differentieringskriterie (Harwood 1796); andre baserede deres klassifikation på et tam-vild-kontinuum (Brookes 1763-72, I:xxvi); og atter andre brugte dyrenes tænder og fødder som den definitive variable (Pennant 1771).

På trods af disse åbenlyse forskelle mellem de klassifikatoriske systemer, som også blev genstand for lidenskabelige debatter igennem århundredet, er der, når de klassifikatoriske systemer sammenlignes, dog ingen tvivl om, at de strukturelt set var af samme slags: Skønt den specifikke definition af forskelle og ligheder varierede, og kategorier således blev indholdsudfyldt forskelligt, var det i det store hele den samme slags af kategorier (arter, genera, ordner, klasser, riger, om end deres benævnelse kunne variere), relateret til hinanden på den samme måde (et inklusivt hierarki), som strukturelt set kendetegnede periodens klassifikationssystemer. Alle var de hierarkisk inklusive klassifikationssystemer, der sigtede mod at udvinde ,,det essentielle“ og ,eviggyldige“ i naturen, og således etableredes alle som systemer, der transcenderede både tid og rum. ${ }^{7}$ Med observationen af denne lighed på et strukturelt niveau er det altså nærliggende at antage, at zoologernes klassifikatoriske praksis var præget af fælles forudantagelser, af det, vi med Anne Knudsen (1989:48) kan kalde for et „kulturelt episteme“.

Zoologerne selv var i deres arbejder meget eksplicitte i forhold til deres umiddelbare (kulturelle) referenceramme. Som vi så tidligere, blev det taget for givet, at alle naturens observerbare individer var organiseret i en altomfattende Orden, og zoologien 
blev iscenesat som en bestræbelse på taksonomisk at rekonstruere denne Orden. Skønt denne Orden var placeret uden for menneskets opfattelsesevne, gjorde zoologerne, som andre af tidens lærde, sig dog alligevel mangfoldige tanker om den store Ordens gestalt. Det var i særdeleshed igennem to nært forbundne idékomplekser, at denne orden blev begrebsliggjort.

Man opererede med en idé om alt varendes store kaede (the Great Chain of Being) eller, med den latinske betegnelse, scala naturae, naturens stige, hvori alt i universet fra Gud og englene i himlen over mennesket, dyrene og planterne til de mindste mineraler i jorden antoges at være forbundet i en lang, stabil og hierarkisk organiseret kæde af forskelle og ligheder: ,Skaberens værker er kædet sammen i en ubrudt perfekt kæde på en sådan måde, at ingen absolutte skel er mulige“" (Berkenhout 1769-72, I:viii). Mennesket selv var i denne kæde eksempelvis på en og samme tid forbundet med dyrene, fordi men-nesket som dem havde en legemlig eksistens; samtidig var mennesket adskilt fra dyrene og omvendt forbundet med de ,rene intelligenser“, englene, fordi mennesket også var et åndeligt væsen. I princippet ville hver eneste art på lignende vis på en gang være forbundet med og adskilt fra de omkringstående arter (jf. Lovejoy 1948). Det var karakteristisk for scala naturae, at den ikke alene var givet af Gud, men eftersom den hidrørte fra en Gud, der en gang for alle havde skabt naturen og alle dens arter ved verdens begyndelse, var den også eviggyldig og stabil.

I tæt samspil med forestillingen om scala naturae udvikledes i perioden desuden et begreb om oeconomia naturae. Oeconomia naturae indebar en forestilling om, at naturen naturligt holdt ledene i det værendes kæde i skak ved, ikke sjældent med voldsomme midler, at underordne ethvert led under det foregående højere rangerende. Med denne forestilling fik scala naturaes stabilitet sig en forklaring. Således blev for eksempel større dyrs rov på andre dyr forklaret som et eksempel på Guds store visdom, fordi de ved at æde de hurtigt formerende mindre dyr bidrog til at holde bestanden i ave og således til at fastholde de mindre dyr på deres rette plads på naturens stige (se f.eks. Anonym 1777:iv-v). Det er centralt her, at mens enkelte individer i naturen nok fødtes, voksede op, måske blev dræbt og ædt, men under alle omstændigheder på et eller andet tidspunkt døde og forgik, mens enkeltindivider altså forandrede sig over tid, ville naturen med dens økonomi sørge for, at forholdet mellem dyrene på artsniveau for altid forblev konstant. Foranderligheden fandtes alene på det konkretes niveau; konstansen alene på det generelles (Smellie 1790, II:435-6).

Tilsammen tilvejebragte forestillingerne om naturens stige og økonomi en kosmo-logisk forklaring på universets Orden og dens måde at fungere på. Det var dette forestillingsunivers, der indbefattede en stabil, ja eviggyldig, hierarkisk verdensorden, som dannede baggrunden for den taksonomiske klassifikationen af dyr i en orden uafhængig af tid og sted. Skønt rekonstruktionen af scala naturae af zoologerne selv blev fremstillet som klassifikationens ultimative om end umulige mål, er det dog bemærkelsesværdigt, at zoologerne fuldstændigt gennemgående i deres arbejder ikke indskrev alverdens dyr i én lang kæde i deres klassifikationer. Zoologerne udpegede godt nok af og til mellemliggende led - polyppen udpeges eksempelvis af de fleste som overgangen mellem dyr og planter, orangutangen som forbindelsesled mellem dyr og mennesker og reptilerne som den orden, der forbandt kvadrupeder og fisk (f.eks. Smellie 1790, II:433-4). Men i modsætning til scala naturae, der fremstod som et eksklusivt hierarkisk system, hvor hvert enkelt led ikke var inkluderet i den højerestående kategori - nøjagtig som soldater i det 


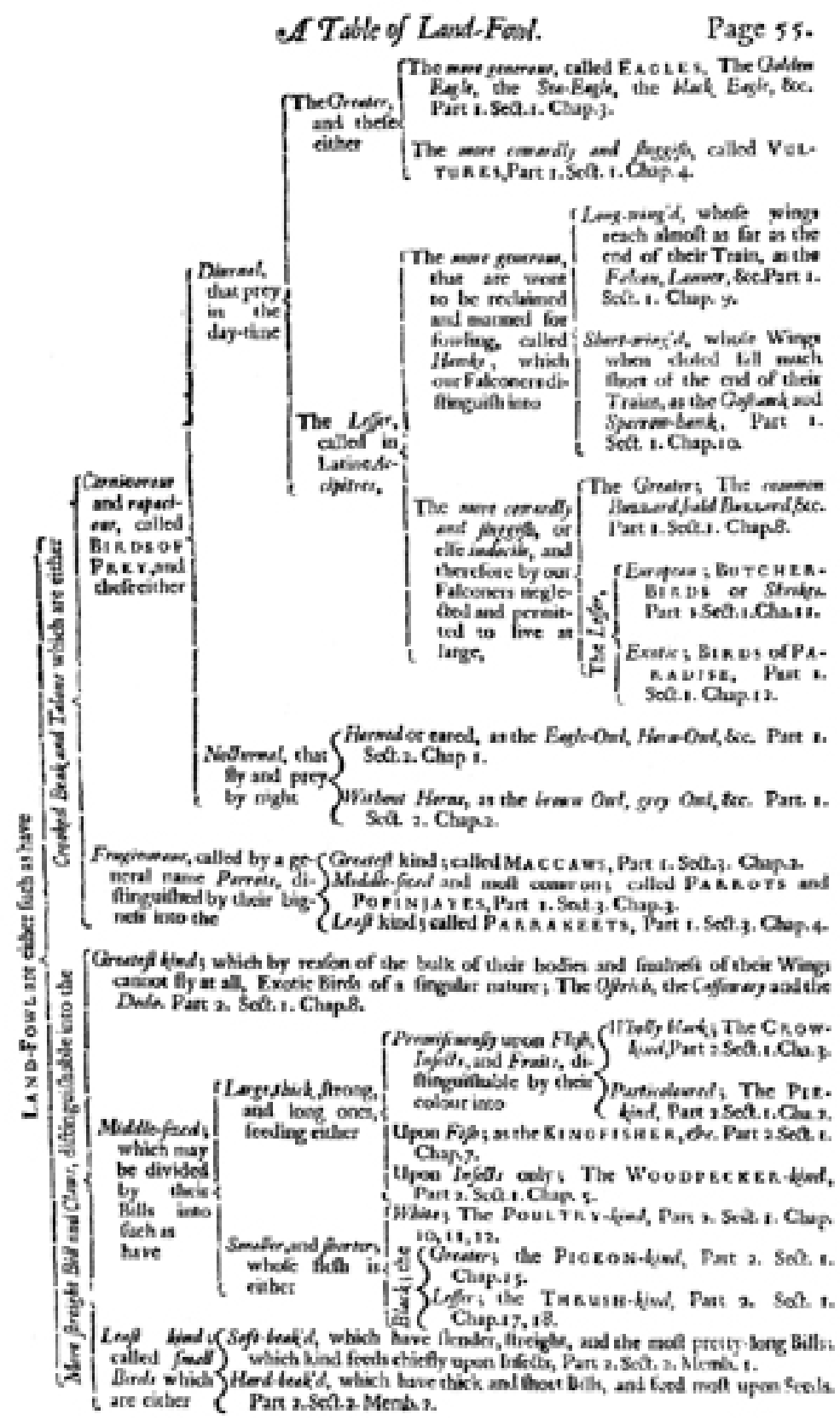

Ill. 5. De zoologiske systemer, der blev opstillet gennem den taksonomiske klassifikation, lignede i langt højere grad et forgrenet træ end den ene lange perfekte kæde - "the great chain of being" - som man forestillede sig, at Gud havde forbundet alverdens forekomster i. I dette eksempel ses kun en skematisering af kategorier i familien fjerkræ (Willughby 1678). 
militære hierarki - skabte zoologerne i deres faktiske klassifikation et inklusivt hierarki, hvor hver enkel laverestående kategori inkluderedes i de højere rangerende kategorier. Snarere end en kæde ville den visuelle metafor for det 18. århundredes britiske zoologiske klassifikationssystemer have været et stærkt forgrenet træ (se ill. 5).

Den kosmologiske orden, som i udgangspunktet gav mening til de klassifikatoriske praksisser, blev således ikke ganske enkelt reproduceret i de klassifikatoriske systemer: I forsøget på at overkomme kløften mellem verden-som-forvirrende og verden-som-Ordnet gennem samlingen af eksemplarer i arter og af arter i genera, genera i ordner og så videre skabtes en langt mere kompleks orden end scala naturaes perfekt simple, uopnåelige Orden.

\section{0-tals-totemisme}

Hvad var det, det 18. århundredes zoologer opnåede ved at skabe denne orden i dyreriget, når det tydeligvist ikke var en perfekt rekonstruktion af naturens egen Orden? Hvad kunne formålet have været med denne kategoriale samling af dyr, når det nu alligevel ikke var muligt at finde frem til Guddommens eget Design? Zoologerne selv angav ofte i indledningerne til deres værker et temmeligt enslydende formål med deres forehavende, som eksempelvis her Sir Thomas Pope Blount:

Hvem end, der Besigtiger UNIVERSETS Kuriøse System, vil aldrig kunne forestille sig, at så Nobel en Struktur skulle være blevet frembragt til ingen anden Nytte, end for at MENNESKET kan leve og ånde i den. Det var sandelig den store Arkitekts Hensigt, at hans Skabning ikke alene skulle levere Fornødenheder og Husly til den dyriske del af os, men desforuden også give anvisninger til vor Intellektuelle. Enhver Blomst på Marken, enhver Fiber i en Plante, enhver Partikel i et Insekt bærer i sig deres Skabers Indpragning og kan (hvis de betragtes på behørig vis) læse os Etikkens eller Guddommelighedens tekster (Blount 1696:Preface (upagineret); kurs. og vers. i org.).

Teologisk (og tautologisk) viste den orden, der gennem den lærdes taksonomiske klassifikation lod sig skabe, trods alt hen til Gud. Skønt man aldrig kunne være sikker på en korrespondance mellem den menneskeskabte orden og Guds Orden, så pegede dog selve det forhold, at det var muligt overhovedet at finde en eller anden form for orden i naturen - en ,så Nobel Struktur“ - på en intelligent skaber bag det hele. Menneskets ufuldendte orden kunne trods alt læses som et genskær af Guds perfekte Orden.

Men hvad med ,etikkens tekster”? Hvad var det for ,,anvisninger“ til menneskets intellekt, der desuden kunne fremlæses i naturen? Jeg skal her afslutningsvist tage dette spørgsmål op og spørge til, hvilke implikationer den zoologiske orden og skabelsen af den havde for den menneskelige orden: Hvor efterlod den zoologiske samling mennesket?

Vi er allerede i analysens forløb ovenfor stødt på mennesket en række gange. Vi har set, hvorledes mennesket som art på naturens stige var placeret midt imellem dyrene, der udelukkende havde en kropslig eksistens, og englene, der udelukkende havde en åndelig. Vi har set, hvorledes forskellige mennesker - fra de ignorante vilde og almuen, over sejlerne, handelsmændene og markedsgøglerne til gentlemen'ene - alle kunne bidrage til indsamlingen af de dyr, som udgjorde det prævidenskabelige grundlag for det 


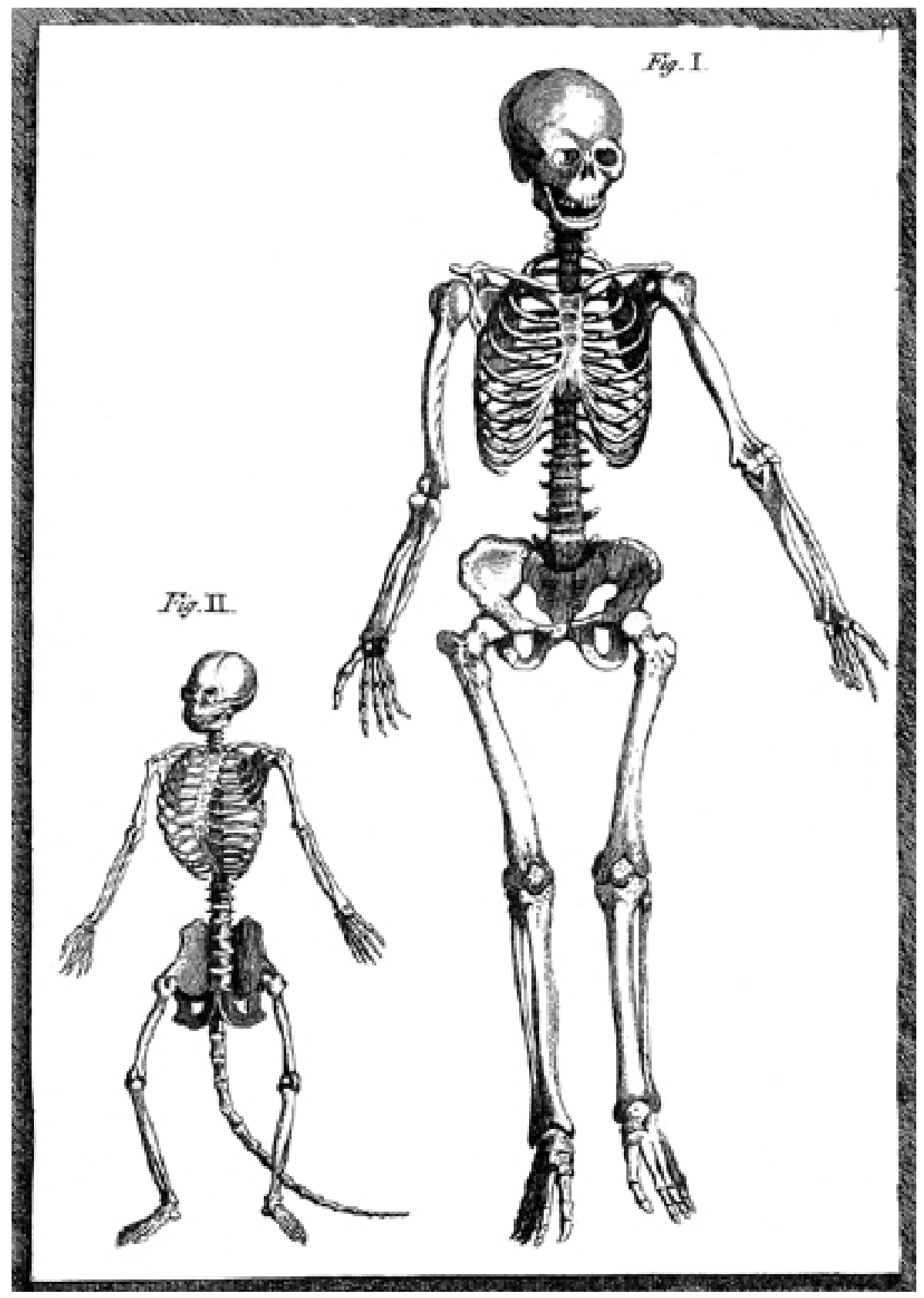

Ill. 6. Forbindelsen mellem abe og menneske forekom indlysende for de fleste af perio-dens zoologer. Ikke mindst ligheder i skelettets bygning blev brugt som et argument for sammenhængen (Bradley 1721). 
zoologiske arbejde. Endelig har vi set, hvordan der skete en udskillelse af menneskearten i forskellige slags - i dem, der kunne ræsonnere, og dem, der ikke kunne - i bevægelsen fra indsamlingen af specifikke dyr til samlingen af dyr i generelle kategorier. Det er på tide nu at undersøge, hvordan disse idéer, dels om menneskeheden som art og dels om uskillelsen af forskellige slags mennesker langs det, en samtidig kaldte for ,en forstandsstige“" (Smellie 1790, I:429), hænger sammen med den zoologiske samling.

Internt havde menneskeheden først og fremmest med reference til besiddelse af gods og guld eller manglen på samme i det 17. århundrede været hierarkiseret langs en vertikal akse (jf. Pocock 1973). „Det er en sand iagttagelse, som vi ikke kan gøre uden Beundring ," som Edward Tyson således bemærkede i sin dedikation til John Lord Sommers, Lord High Chancellor og præsident for det lærde selskab Royal Society, af sin bog om orangutangens anatomi,

At [sic] fra Mineraler til Planter, fra Planter til Dyr, og fra Dyr til Mennesker er Overgangene så gradvise, at der forekommer at være en meget stor Lighed såvel mellem de tarve-ligste Planter og nogle Mineraler, som mellem den laveste Stand af Mennesker og den højeste slags af Dyrene. Det Dyr, hvis Anatomi jeg her har givet [altså orangutangen], nær-mer sig mest Menneskeheden og forekommer at være Bindeledet mellem Dyrene og de Rationelle [dvs. menneskene], på sammen Måde som Deres Lord, og alle andre af Deres Høje Rang og Viden og Visdom, står nærmest den Art af Væsner, der er lige over os [dvs. englene]; De forbinder den Synlige og den Ikke-synlige Verden (Tyson 1699:Dedication).

Lagdelingen af mennesker var altså homolog til den hierarkisk eksklusive lagdeling af dyr, planter og mineraler på naturens stige. Der var imidlertid et aberdabei, som blev stadigt mere markant i løbet af det 18. århundrede, og som betød, at denne homologi mel-lem scala naturae og scala humanae aldrig kunne blive helt perfekt. Modsat mineralerne, blomsterne og dyrene, der alle som materielle forekomster en gang for alle ved verdens begyndelse var skabt, som de var og altid ville være, besad mennesket som et også åndeligt væsen et potentiale for forandring. Anlægget for at tænke og ræsonnere var godt nok givet alle mennesker fra starten - ånden var netop et af artens definitive træk. Men det var alene gennem ,kultur og dannelse“, som Lord Monboddo påpegede, at dette anlæg kunne udvikles og hermed tages i brug: „det er vor arts mest væsentlige og adskillende kendetegn, at vi kan skabe os selv“ (Monboddo 1774, I:24-5; kurs. i org.). En „,mand“ kunne således, som en anden forfatter understregede, ,gennem et seriøst studie erhverve [...] sig en klar og solid dømmekraft [...og] dermed [blive] et væsen af en anden slags, helt forskellig fra de dyriske mænd“ (Barrow 1693:163-4). Det vil sige helt forskellig fra den almue, der ikke havde haft mulighed for at udvikle sit åndelige potentiale. Det var det åndelige anlæg for transformation, som adskilte menneskene fra dyrene, og det var udviklingen af de åndelige anlæg, først og fremmest af fornuftens evne til at sammenligne, som jo også var grundlaget for hele den zoologiske klassifikation, som internt adskilte forskellige slags af mennesker på forstandsstigen:

[I] de fleste viser det rationelle anlæg sig knapt nok, før det er blevet hjulpet frem af uddannelse, erfaring og refleksion. Hvis vi fjerner evnen til at sammenligne en ting med en anden, som er erfaringens fundament, bliver vi ikke meget bedre end dyrene, som alene er behersket af instinkter og sanselig drift; og hvis vi sammenligner de laveste Vilde i vor store art med en Newton eller en Locke, vil jeg tro, at forskellen vil blive anset for at være større end den mellem den Vilde og nogle af hans dyriske følgesvende i skovene og på bjergene (Edwards 1758-64, II:xiii-ix). 
Ved at besidde et sådant åndeligt udviklet sind, at zoologen - modsat almuen - var i stand til at overskue fænomenverdenens forvirrende mangfoldighed ved at samle de konkrete dyr i abstrakte og ordnede klasser, skabte han samtidig en afstand mellem både sig og dyrene og sig og de ,dyriske mennesker“. Hvor alskens mennesker - fra tjenere og endog vilde over sejlere og handelsfolk til zoologerne selv - med visse modifikationer kunne bidrage til indsamlingen af zoologiens materiale på et prævidenskabeligt, empirisk niveau, blev selve den kategoriale samling af dyr i det taksonomiske system forbeholdt en eksklusiv skare af ,,åndeligt oplyste“ filosoffer. Kun de formåede angiveligt at transcendere fænomenverdenens forvirrende mangfoldighed og ane genskæret af Guds bagvedliggende Orden. Ved at udvikle sit åndelige potentiale og hermed fjerne sig fra sin kropslig-dyriske eksistens kunne den lærde således nærme sig englenes position. Nogle lærde gik endog så vidt som til at mene, at den lærde måske engang i fremtiden med yderligere „,kultur“ ville blive i stand til at ,indtage rang af sådanne [væsner], som er umiddelbart over os på det værendes stige“" (Monboddo 1774-92, I:22-3).

Modsat dyrene, der ifølge deres essentielle natur på forhånd var bestemt for én og kun én plads i naturens Orden og dermed kunne indskrives i det taksonomiske systems statiske tabel, var mennesket altså ifølge sin natur grundlæggende foranderligt. Så skønt adskillelsen af menneskearten fra dyrene og hierarkiseringen af mennesker på en forstandsstige var en integreret del af den orden, zoologen gennem sin samling af dyr fik skabt, er det dog værd at bemærke, at homologien mellem den zoologiske og den antropologiske orden her skrider: De to hierarkier lod sig alene integrere i én samling, idet åndens transformation blev introduceret som differentiationskriterie i den menneskelige verden, mens eviggyldige morfologiske og til dels anatomiske træk dannede et statisk grundlag for adskillelsen af dyr i kategorier og samlingen af dem i det taksonomiske system. Med denne uoverensstemmelse mellem den antropologiske og zoologiske klassifikation indførtes således også en grundlæggende adskillelse mellem en foranderlig kultur og en statisk natur. Selvom zoologerne godt nok ikke helt nåede deres mål, at få genskabt Guds perfekte Orden, blev der dog alligevel med den taksonomiske samling skabt orden både i dyrenes og menneskenes verden: Ikke alene blev der skabt arter, genera, ordner, klasser og riger, men i skabelsen af disse fik de lærde også indført en vis orden i universet og i denne skabt ikke så meget en plads som et rum for sig selv, fjernt fra dyrene og de dyriske mennesker på vej mod himlens engle.

\section{Noter}

1. Alle citater er oversat af undertegnede.

2. Med Linnés ord: „Naturvidenskaben baserer sig på et eksakt kendskab til de naturlige forekomsters nomenklatur og deres systematiske opstilling; det er denne, der som Ariadnetråden gør filosoffen i stand til i sikkerhed at rejse gennem de snørklede bugter i naturens labyrint" (Linné 1766-68, I:13).

3. En undersøgelse af 104 naturhistorikere, der udgav skrifter i perioden 1660-1800, har vist, at omkring tre fjerdedele af disse kom fra middelklassen og i særdeleshed fra de såkaldte „lærde professioner”: medicin, kirke og læreanstalter. Den resterende del fordelte sig på aristokrater, embedsmænd og handelsmænd. Se i øvrigt også Hans (1951:30ff.).

4. Dette summariske rids af de grundlæggende koordinater i den indfødte kognitive model for erkendelse og klassifikation trækker først og fremmest på Harris (1751), Hume (1739-40, 1748), Locke (1997 [1706]), Monboddo (1774-92). Det følgende yder selvsagt på ingen måde de faktisk temmeligt sofistikerede teorier 
retfærdighed; for en mere uddybende behandling se Richetti (1983), Rorty (1980:især kap. 1).

5. Det bør noteres her, at der var en vis uenighed blandt filosoffer om, hvordan et ,usammensat element“ præ-cist skulle defineres. John Locke mente således, at mennesket alene var i stand til at opfatte enkeltelementer, som for eksempel med Lockes eget eksempel en svanes farve, dens lange hals, dens røde næb, dens sorte ben etc., som dernæst i sindet blev samlet til en helhed, i dette tilfælde en svane (Locke 1997 [1706]:276; II,xxiii,14; jf. Monboddo 1774, I:36ff.). Andre som for eksempel James Harris antog derimod, at mennesket var i stand til at sanse for eksempel et enkelt dyr som en entitet (Harris 1751:39). Uanset hvordan ,element“ specifikt blev defineret, er det vigtige i denne sammenhæng, at det for alle filosoffer alene var enkelte, usammensatte elementer i den fysiske verden, der lod sig opfatte.

6. I den deduktive klassifikation startede zoologen almindeligvis med hele den naturlige verden, der oftest ville blive inddelt i „,besjælet“ og ,ubesjælet liv“, det vil sige i dyr og planter på den ene side og mineraler på den anden; det „,besjælede liv“ blev så igen underinddelt i ,dyr“ og ,planter”; ,dyr“ blev dernæst underinddelt i ,klasser“ og disse i ,ordner“.

7. Det var i særdeleshed på klassifikationssystemernes højere niveauer, at udeladelsen af rummet, det vil sige dyrenes habitat, bliver synlig: I klassifikationen af arter i genera er det kun yderst sjældent, at der blev gjort brug af et dyrs levested. Denne udgrænsning af rummet var tæt forbundet med udeladelsen af tiden. I det 18. århundrede opererede stort set alle britiske zoologer med en tidshorisont på små 6000 år, idet jordens skabelse almindeligvis blev fastsat til 4004 år f.Kr. (På kontinentet var der dog enkelte som for eksempel den franske naturhistoriker Count de Buffon, der opererede med meget længere tidsperspektiver). Der var således kun i meget ringe grad levnet tid til at indtænke udvikling af arter, og herunder udvikling af arter i samspil med deres naturlige omgivelser, i zoologien. Det bør dog understreges, at zoologerne rent faktisk diskuterede nogle ændringer af dyr over tid. Ikke mindst i avlsarbejdet med forskellige husdyr var det tydeligt, at det til en vis grad var muligt at ændre dyr over tid, ligesom transporten af dyr fra deres oprindelige levested til nye lokaliteter, der ikke mindst fulgte med kolonisationen, også gav næring til spekulationer over forandringer i dyr i relation til tid og rum. Endelig spillede rummet også en væsentlig rolle i de auto-antropologiske forklaringer af menneskeracernes forskellighed (se f.eks. Wilson 1780). Men det var stort set alene på det laveste niveau af afarter, det vil sige variationer af arter (som også menneskeracer blev defineret som), at tid og rum blev medtænkt. Det var altså almindeligvis kun „små“ forskelle, som rummet i forening med tiden blev brugt til at forklare.

\section{Litteratur}

Anonym

1776 Some Memoirs of the Life and Works of George Edwards. Fellow of the Royal and Antiquarian Societies. London.

Anonym

1777 Beauties of Natural History; or, Elements of Zoography, being a short and pleasant Introduction to an Acquaintance with the Nature and Qualities of the Animals World: ivested of all Fabulous Absurdities. - Selected from the Most Celebrated Naturalists, and Arranged under the General Heads of Quadrupeds, Fowls, Fishes, Lizards, Insects, \&c. Describing all the Capital Characteristicks of the Most Distinguished Individuals, in every Separate Class; Their Discriminating Habits of Life; Their Social, Savage, Active, or Indolent Dispositions; the Regular Economy and Government of Some, the Singular Sagacity of Others, and the Wonderful Instinct of All. With a Preliminary Essay, On the Pleasure and Advantage of this Science. The Whole Illustrated by a great Variety of Copper-Plates, Engraved from Nature. London: Richardson \& Urquhart.

\section{Ardener, Edwin}

1989 The Voice of Prophecy and Other Essays. M. Chapman (ed.). Oxford: Blackwell.

Atran, Scott

1990

Cognitive Foundations of Natural History. Towards and Anthropology of Science. Cambridge: Cambridge University Press.

Bancroft, Edward

1769 An Essay on the Natural History of Guiana, in South America. Containing a Description of many Curious Productions in the Animal and Vegetable Systems of that Country. Together with an Account of the Religion, Manners, and Customs of Several Tribes of its Indian 
Inhabitants. Interspersed with a Variety of Literary and Medical Observations. In Several Letters from a Gentleman of the Medical Faculty, During his Residence in that Country. London: T. Becket \& P. A. De Hondt.

Barker, Hannah \& Elaine Chalus

1997 Gender in Eighteenth-Century England. Roles, Representations and Responsibilities. London \& New York: Longman.

Barrow, Isaac

1693 Of Industry in Five Discourses: Viz. In General. In our General Calling, as Christians. In our Particular Calling as Gentlemen. In our Particular Calling, as Scholars. London.

Berkenhout, John

1769-72 Outlines of the Natural History of Great Britain and Ireland. Containing a Systematic Arrangement and Concise Description of all the Animals, Vegetables, and Fossils which have hitherto Been Discovered in these Kingdoms. Vol. I-III. London: P. Elmsley.

Blount, Sir Thomas Pope

1693 A Natural History: Containing many not Common Observations: Extracted out of the best Modern Writers. London.

Bradley, Richard

1721 A Philosophical Account of the Works of Nature, Endeavouring to Set Forth the Several Gradations Remarkable in the Mineral, Vegetable, and Animal Parts of the Creations, ending to the Composition of a Scale of Life. To which Is Added an Account of the State of Gardening as It Is now in Great-Britain and other Parts of Europe: Together with Several New Experiments Relating to the Improvement of Barren Ground, and the Propagation of Timber-Trees, Fruit-Trees, \&c. With many Curious Cuts. London.

Brookes, R.

1763-72 A New and Accurate System of Natural History; Containing I. The History of Quadrupeds, including Amphibious Animals, Frogs, and Lizards, with their Properties and Uses in Medicine. II. The History of Birds, with the Method of Bringing up those of the signing Kind. III. The History of Fishes and Serpents, including Sea-Turtles, Crustaceous and ShellFishes; with their Medical Uses. IV. The History of Insects, with their Properties and Uses in Medicine. V. The History of Waters, Earths, Stones, Fossils, and Minerals; with their Virtues, Properties, and Medical Uses: To which Is Added, the Method in which Linnæus Has Treated these Subjects. VI. The History of Vegetables, as well Foreign as Indigenous, including an Account of the Roots, Gums, and Concrete Juices; as also their Properties, Virtues, and Uses in Medicine; together with the Method of Cultivating those Planted in Gardens. Vol. I-VI. London: J. Newbery.

Brown, Peter

1776 New Illustrations of Zoology, Containing Fifty Coloured Plates of New, Curious, and nondescript Birds, with a Few Quadrupeds, Reptiles and Insects. Together with a Short and Scientific Description of the Same. London: B. White.

Buffon, George-Louis Leclerc count de

1780 Natural History, General and Particular, by the Count de Buffon, Translated into English. Illustrated with 260 Copper-Plates, and Occasional Notes and Observations by the Translator. William Smellie (overs. og red.). Vol. I-VIII. Edinburgh.

Cesalpino, Andrea

1583 De Plantis, Libri XVI. Firenze.

Critical Review

$1763 \quad$ Critical Review, Oktober.

Edwards, George

1743-51 A Natural History of Birds. Most of Which Have Not Been Figur'd or Describ'd, and Others Very Little Known from Obscure or to Brief Descriptions without Figures, or from Figures Very Ill Design'd. Containing The Figures of Sixty Birds and Two Quadrupedes, Engrav'd on Fifty-Two Copper Plates, after Curious Original Drawings from Life, and exactly 
Colour'd. With Full and Accurate Descriptions. Vol. I-IV. London: College of Physicians.

Gleanings of Natural History, Exhibiting Figures of Quadrupeds, Birds, Insects, Plants, \&c. Most of Which Have Not, till Now, Been either Figured or Described. With Descriptions of Seventy Different Subjects, Designed, Engraved, and Coloured after Nature, on Fifty Copper-Plate Prints. Vol. I-III. London: Royal College of Physicians.

Hans, Nicholas

$1951 \quad$ New Trends in Education in the Eighteenth Century. London: Routledge \& Kegan Paul.

Harris, James

1751 Hermes: Or, a Philosophical Inquiry Concerning Language and Universal Grammar. London: H. Woodfall.

Harris, Moses 1766

The Aurelian: or, Natural History of English Insects; namely, Moths and Butterflies; together with the Plants on which They Feed, a Faithful Account of Their Respective Changes, Their Usual Haunts when in the Winged State, and Their Standard Names, as Given and Established by the Worthy and Ingenious Society of Aurelians. Drawn, Engraved and Coloured from the Natural Subjects Themselves. London.

Harwood, Busick

1796 A System of Comparative Anatomy and Physiology. Cambridge: J. Burges to the University.

Hume, David

1978 [1739-40] A Treatise of Human Nature: Being an Attempt to Introduce the Experimental Method of Reasoning into Moral Subjects. L. A. Selby-Bigge \& P. H. Nidditch (eds.). 2. udg.

Oxford: Clarendon Press.

1988 [1748] An Enquiry Concerning Human Understanding. New York: Prometheus Books.

Jørgensen, Bent

1998 Paradisfuglene - fra fantasi til virkelighed. Naturens Verden:1-14.

Kentish, Richard

1787 An Essay on the Method of Studying Natural History: Being an Oration Delivered to the Societas Naturæ Studiosorum, at Edinburgh, in the Year 1782. London: P. Elmsley \& J. Johnson.

Knudsen, Anne

1989 En $\varnothing$ i historien. Korsika. Historisk antropologi 1730-1914. København: Basilisk.

Lévi-Strauss, Claude

1964 [1962] Totemism. London: Merlin Press.

1994 [1962] Den vilde tanke. København: Gyldendal.

Linné, Carl von

1766-68 Systema Naturæ per Regna tria Naturæ, Secundum Classes, Ordines, Genera, Species, cum Characteribus, Differentiis, Synonymis, Locis. 12. udg. Vol. I-III. Holmiæ: Laurentii Salvii.

1792 The Animal Kingdom, or Zoological System, of the Celebrated Sir Charles Linnæus; Class I. Mammalia: Containing a Complete Systematic Description, Arrangement, and Nomenclature, of all the Known Species and Varieties of the Mammalia, or Animals which Give Suck to their Young; Being a Translation of that Part of the Systema Naturæ, as Lately Published, with Great Improvements. R. Kerr (overs. \& red.). London: J. Murray \& R. Faulder.

Locke, John

1997 [1706] An Essay Concerning Human Understanding. London: Penguin Books.

Lovejoy, Arthur O.

1948 The Great Chain of Being. A Study of the History of an Idea. Cambridge, Mass.: Harvard University Press.

Monboddo, Lord

1774-92 Of the Origin and Progress of Language. Edinburgh.

Pennant, Thomas 
Pocock, J. G. A.

1973 Politics, Language and Time. Essays on Political Thought and History. New York: Atheneum.

Pratt, Mary Louise

1992 Imperial Eyes. Travel Writing and Transculturation. London \& New York: Routledge.

Richetti, John

1983 Philosophical Writing: Locke, Berkeley, Hume. Cambridge: Harvard University Press.

Rorty, Richard

1980 Philosophy and the Mirror of Nature. Oxford, UK \& Cambridge, Mass.: Blackwell.

Schiebinger, Londa

1993 Nature's Body. Gender in the Making of Modern Science. Boston: Beacon Press.

Shapin, Steven

1994 A Social History of Truth. Civility and Science in Seventeenth-Century England. Chicago \& London: The University of Chicago Press.

Shapiro, Barbara

1983 Probability and Certainty in Seventeenth-Century England. A Study of the Relationship between Natural Science, Religion, History, Law, and Literature. Princeton: Princeton University Press.

Shaw, George

1792 Museum Leverianum, Containing Select Specimens from the Museum of the late Sir Ashton Lever, Kt, with Descriptions in Latin and English . London: James Parkinson.

Smeathman, Henry

1781 Some Account of the Termites, which Are Found in Africa and other hot Climates. In a Letter from Mr. Henry Smeathman, of Clement's Inn, to Sir Joseph Bank, Bart. P. R. S. Philosophical Transactions LXXI(1):139-94.

Smellie, William

1790 The Philosophy of Natural History. Vol. I-II. Dublin: William Porter.

Tyson, Edward

1699 Orang-Outang, sive Homo Sylvestris. Or, the Anatomy of a Pygmie, Compared with that of a Monkey, and Ape, and a Man. To which Is Added, A Philosophical Essay Concerning the Pygmies, the Cynocephali, the Satyrs, and Sphiges of the Antients. Wherein It Will Appear that They Are all either Apes or Monkeys, and not Men, as formerly Pretended. London.

White, Gilbert

1770 Brev til Thomas Pennant, 29. okt. British Library, MSS, Add. 35.138, ff. 43-4.

Willughby, Francis

1972 [1678] The Ornithology of Francis Willughby of Middleton. Facsimile kopi. Menston: The Scholar Press Limited.

Wilson, Alexander

$1780 \quad$ Some Observations relative to the Influence of Climate on Vegetable and Animal Bodies. London: T. Cadell.

Woodward, John

1696 Brief Instructions for Making Observations in all Parts of the World: as Also for Collecting, Preserving, and Sending Over Natural Things. Being An Attempt to settle an Universal Correspondence for the Advancement of Knowledge both Natural and Civil. London.

Yeats, Thomas Pattinson

1773 Institutions of Entomology; Being a Translation of Linnæus's Ordines et Genera Insectorum; or, Systematic Arrangement of Insects. Collated with the Different Systems of Geoffroy, 
Schæffer and Scopoli; together with Observations of the Translator. London: R. Horsfield. 